\title{
Folklorism in Ukrainian Gotho-Romantic Prose: Oleksa Storozhenko's Tale about The Devil in Love (1861) (1)
}

\author{
Svitlana Krys \\ Modern Languages and Cultural Studies \\ University of Alberta \\ Edmonton, Alberta, Canada
}

Abstract

Oleksa Storozhenko's (1806-1874) long story “Закоханий чорт” [Devil in Love] (1861) reveals close parallels to the eponymous novella of the French Gothic author, Jacques Cazotte (1719-1792; Le Diable amoureux [The Devil in Love, 1772]). However, literary criticism left this connection uncommented on and emphasized only the folklore of Storozhenko's work. This article aims to examine whether Storozhenko was indeed inspired by folklore alone, which would make his connection to Cazotte's narrative coincidental. I will subject the folkloric stratum in his tale to in-depth analysis, utilizing a combination of motif (Thompson), tale type (Aarne, Thompson, and Uther), and structural (Propp) methods for the assessment and classification of oral narrative.

While my study shows that Storozhenko's tale does invoke the universal folkloric motif of love between a mortal and the devil and adheres to Propp's structure of a typical folktale, the application of the ATU index does not return any folktale type that could serve as a model for the 'devil in love' narrative. Moreover, a few collections of Ukrainian folktales that I consulted also do not have a specific tale that would at least remotely remind us of Storozhenko. Thus, my findings show that Storozhenko's tale merely exudes a folkloric allure, which must have prevented the scholars from searching for its antecedents beyond strictly oral tradition. But the fact that Storozhenko selected folktale motifs that resemble Cazotte's and stylized them in a similar manner, proves my hypothesis that the two are intertextually linked. This also shows that Storozhenko produced a peculiar mode of the Gothic that followed his French predecessor's practice in utilizing metafolkloric allusions, but instead of exotic elements he turned to local Ukrainian legendary and historical tradition to fill its framework. 


\section{Introduction}

Two prominent Gotho-Romantic authors, the Frenchman Jacques Cazotte (1719-1792) and the Ukrainian Oleksa Storozhenko (18061874), have each written a tale about the devil in love (Le Diable amoureux [1772] and "Закоханий чорт" [1861]) that are very similar in terms of plot and style, not to mention the identical title. Both tales exhibit the following parallels (I will limit myself to just a few examples): a military protagonist comes in contact with the supernatural realm; he makes a contract with the Devil, which puts the Devil in a position of servitude to him; the protagonist falls in love with a demonized female character; he attempts to rescue her from the grips of evil; a holy man mediates; and there is a successful/unsuccessful marriage at the end of the protagonist's adventure. The narrative technique, utilized in both stories, is in the form of the skaz (i.e., it imitates an oral narrative) and the style is frenetic. I have already addressed the tales' intertextual relations in a previous article, which showed a high probability that Storozhenko based his story on Cazotte [Pavlunik (Krys) 2006: 27-34]. However, one persistent issue that stems from my previous research and still dogs Storozhenko's tale is its purported connection to folklore, i.e., the possibility that he might have been inspired, independently of Cazotte, by some Ukrainian oral narrative that has its origins in the European myth of 'the devil in love'. This universal $u r$-myth could have served as background for Cazotte as well, and this, therefore, would account for plot and title similarities between their works. This is especially interesting, given the fact that critics in the past assumed that Storozhenko drew on folklore alone.

This article proposes to move beyond suppositions and investigate the folkloric stratum in Storozhenko's tale, utilizing a combination of motif (Thompson), tale type (Aarne, Thompson, and Uther), and structural (Propp) methods for the assessment and classification of oral narrative. I will start by examining the reasons why scholars assumed only ethnographic origins for Storozhenko's tale. Primarily, I will compare and contrast his tale to the folk narratives about the Devil, featured in several collections of Ukrainian folktales from the 19th and 20th centuries. Subsequently, I will draw on Thompson's motif index and Propp's proposed universal structure of a folktale to highlight the mechanisms and features that make Storozhenko's tale exhibit a distinct folkloric allure. Finally, I will bring in Aarne-Thompson-Uther's universal tale types' index, in order to analyze whether the ur-narrative 
about the devil in love (as presented in Storozhenko's and, before him, Cazotte's tales) exists. Based on my findings, I will refute the idea that Storozhenko grounded his tale on some folkloric plot, by showing that there is no such universal tale type as 'the devil in love' among the tale types present in Aarne-Thompson-Uther's index, and that the folktale motifs he selected for his tale and the manner in which he stylized them closely follow Cazotte. This will allow me to state with certainty that the textual parallels, which Storozhenko's tale exhibits to Cazotte's, are not a folkloric coincidence, and that it does find its antecedent in literaturenamely, in the occult Gothic novella of his French predecessor. At the end, I will offer generalized conclusions as to the place of Storozhenko's tale within the Ukrainian Gothic canon and the peculiar mode of the Gothic he constructed that followed the model of his French predecessor in utilizing metafolkloric allusions to fill its framework but instead of exotic elements turned to local Ukrainian legendary and historical tradition.

But before I proceed, a brief summary of each tale is in order to review the intertextual parallels between the two.

\section{Tales' synopsis}

Cazotte's main protagonist, don Alvaro Maravillas, is a military man who leads a debauched life and is interested in all things mysterious. He believes that they will give him access to higher knowledge and supernatural powers. His military colleague, Soberano, takes Alvaro to a forlorn cave in the woods one night where, owing to his courage and ability to conquer fear, he conjures the Devil himself who first scares Alvaro by appearing before him in the dreadful image of a camel's head, which later turns into a dog, and then into the spirit of the air, sylphide, and becomes Alvaro's servant, a page. Alvaro sees the latter in both male and female hypostases (Biondetto and Biondetta), and is torn between a female and a male image of the Devil. Clearly understanding the constraints of social conventions, Alvaro attempts to turn away from the male, that is, his homosexual side, and falls in love with the feminine image of the servant, Biondetta. Having devoted himself to the page, Alvaro forgets about his military duties and leads a social life. His devotion to Biondetta and abandonment of his military duties is his first misstep on the path to becoming the Devil's prey. Fortunately, his mind is still trying to follow societal norms: he understands that for his union with Biondetta to succeed, he needs to introduce her to his mother (who 
is described in the novella as a saint incarnate) and to obtain her holy blessing. By doing so he wants to remove any bonds Biondetta might still have to the supernatural realm-to purify her, so to speak. On their way to Alvaro's mother, he avoids any physical contact with Biondetta. $\mathrm{He}$ is afraid to give in to his feelings without societal, i.e., Church and parental approval, and suspects that such an action might bring to the surface something dark and demonic. Alvaro's apprehensions indeed become true. When he finally gives in to Biondetta's sexual demands, she no longer comes to him in the image of a woman. What appears instead is the Devil, a male symbol, the threatening Beelzebub. At the end, only a conversation with his righteous mother and a priest saves Alvaro's sanity. These two remind him of societal norms as well as his duty to marry a respectable lady and hence, try to remove the image of the Beelzebub from his mind but the reader never learns if they succeed.

Storozhenko's "Devil in Love" weaves together several stories by different narrators. The first speaks about himself, his military service and his rare visits home. During one such visit to Ukraine, he meetswhile resting at a forlorn wayside inn - an old bandura player who narrates to him the story about a devil in love. The events in the story, it turns out, happened to the bandura player's grandfather, Kyrylo Kelep, approximately one hundred years ago. Kyrylo Kelep was then a young Zaporozhian Cossack and a kharakternyk (i.e., a sorcerer). Thus, like Alvaro, Kyrylo is a military man, possessing some sort of supernatural powers. One night he too happens to be in the woods, in a disconcerting unfamiliar location, where he falls asleep. In his dream he suddenly sees demonic forces, anthropomorphized in the persona of a Devil, named Trutyk, and a witch, named Odarka, to whom the former declares his love. Like Alvaro who falls in love with the demonic being, Kyrylo also develops feelings for the witch. But Storozhenko's protagonist is not torn between the desire for the male and the female image of the supernatural. $\mathrm{He}$ is rather torn between his societal obligations, which prevent any contact with women while the Cossack serves at the Sich, and his budding desire for Odarka (it is for this reason that Odarka is seen by Kyrylo as a witch (2)). These feelings for Odarka, which are prohibited by the military code of the Cossacks, become demonized in Kyrylo's subconscious and appear before him in his dream in the image of the Devil. Kyrylo learns that Odarka was forced into demonic service and decides to assist her quest to save her soul and free herself from the Devil's bond. While Cazotte's Alvaro plans to take Biondetta to his virtuous mother to bless their union and, by extension, remove her 
supernatural fetters, i.e., make her "human," Kyrylo persuades the Devil to take Odarka to a holy hermit for the same purpose. To do so, the Devil metamorphoses into a horse, which offers yet another parallel to Cazotte's narrative, where the Devil also took the form of an animal-a camel's head and later a dog. (3) Unlike Alvaro whose debauchery in the army has corrupted him and made him vulnerable to the dark forces that almost overpowered him at the end of his journey, Kyrylo is able to take the right path from the very beginning and withstand evil temptation. $\mathrm{He}$ follows the hermit's advice to the letter and, therefore, manages to subdue his "inner" Devil and assist Odarka in saving her soul. After five years of performing his societal obligations and military duties, Kyrylo returns to the hermit and marries Odarka, at which time the Devil is torn apart by ravens in a particularly unnerving Gothic scene.

\section{Metafolkloric references}

Storozhenko's literary activity was nurtured by Ukrainian folklore. He himself speaks of it in his letters [1989b: 561-586], and a number of scholars (such as Mykola Zerov [2003: 750-752], Bohdan Lepkyi [1954: 6-7], Arsen Ishchuk [1957: 15], Petro Khropko [1989: 12-13], Uliana Baziuk [2003: 172], and V. Pohriebennyk [2008: 2-7]) attested to this fact. To give just one example: Khropko notes that "О. Стороженко майстерно вибудовує оригінальні сюжети на каркасі прислів'я чи приказки, за мотивами переказу, легенди, повір'я" [Storozhenko artfully creates original plots, basing himself on the outline of a proverb, or following an oral narrative, a legend, or a folk belief] [1989: 12]. In terms of Storozhenko's tale "Devil in Love," Khropko states that it is based on a legend about the amour between the Devil and a witch, as well as on a number of folk narratives about resourcefulness and the quick wit of Zaporozhian Cossacks [1989: 13]. (4) Unfortunately, Khropko does not cite any specific folkloric sources to prove his statement. It is easy to agree with him as to the second, more general part of his statement regarding the folklore about Zaporozhian Cossacks because there are many folkloric elements in "Devil in Love." (5) However, the absence of any bibliographic references to a specific legend, on which Khropko thinks Storozhenko built his tale, is surprising and raises doubt about his assertion. I examined several collections of Ukrainian folktales and legends, collected and published during the 19th and 20th centuries [Mikhail Dragomanov 1876; Boris Grinchenko 1901; Volodymyr Hnatiuk 1912; Mykola Levchenko 1928; Anatolii Ioanidi 
1985; Mykola Zinchuk 2003], and not one features a story, similar to Storozhenko's. Here are a few examples of the themes of the tales in these collections. Some deal with how the Devil can befuddle a person, turning, what appears to be a valuable gift, into nothing but a heap of dust or coal; others show the Devil as a rich man (pan) or as an animal who vanishes with the rooster's crowing. (6) Still others tell us about the Devil's attempts to capture human souls, or narrate how people met with the Devil and what came of it. (7) There are also stories that focus on the process of conjuring the Devil and turning him into a servant. (8) While there are some that end tragically in human death, especially the ones from Hnatiuk's collection (1912), the majority of the tales have a happy ending where the Devil fails to lure human souls either with riches or false promises, and is often outwitted by clever and pious peasants. (9) As this summary shows, there is very little about love in these stories, and in all the collections I considered only a few tales focus actually on the Devil and a woman. (10) Almost all of the tales are about a man's (and not a woman's) encounter with the Devil. The women, appearing in these stories, play mostly an auxiliary role of wife to the man who comes into contact with the Devil. (11) As for the witch part of Storozhenko's narrative, there is some overlap with tales about witches, collected by Hnatiuk, but it appears in minor details only, related to the description of a witch-e.g., a tail that witches typically have or a witch's ability to transform herself into an animal, specifically a hound [Hnatiuk 1912: 99, 118], as Odarka does in "Devil in Love"-but not in the overall plot structure.

Hence, Khropko's statement about the existence of a specific legend of love between the Devil and the witch may be regarded as an example of meta-folklore (i.e., folklore about folklore) -in other words, an assumption about the existence of folkloric sources for the text, which resembles a folkloric narrative both thematically and structurally. A similar allusion occurs in the tale "Biй" [Vii] (1835) by Nikolai Gogol'/Mykola Hohol' (1809-1852). As Natalie Moyle [Kononenko] shows, the scholars who assumed that "Vii" was based on a specific folkloric source/tale and attempted to pinpoint it, failed in their efforts, since "Vii" is obviously a literary text. What "Vii" does contain is not so much exact individual motifs as deeper folkloric structures, patterns and folkloric logic [Moyle (Kononenko) 1979: 665-667]. Likewise, Storozhenko's text too follows oral tradition in many ways, but remains a distinct literary creation rather than an adaptation from folklore. Let me point to some of these elements, which may account for Khropko's 
statement. First and foremost, his story is close to the genre of legend (maybe, a subgenre of demonic legend) because it takes place in the realistic mode within the frames of historical time and space (e.g., Zaporozhian Sich, and Saint Mountains, which can be found in Eastern Ukraine) and has clear connections with Christian forces (the hermit, the cross, the prayer). (12) Secondly, Storozhenko's plot reflects a universal folkloric motif of love between a mortal and a supernatural figure (here, the Devil) [Thompson 2000]. (13) Within the framework of this broader motif, Storozhenko introduced other, minor folktale elements into his story, such as a contract with the devil, servitude to achieve redemption, riding a devil [Kononenko 2007: 166], and a devil's transformation into an animal [Thompson 2000: Volume 2: D-E, see D102 and D102.1]. Also, if we search under the broader category of "demon" rather than "devil," we will find additional motifs in Thompson's Motif-Index, such as "demon as familiar spirit," "demon lover," and "saint wrests soul from demons," which surface in Storozhenko's tale as well [2000: Volume 2: $D-E$, and Volume 3: F-H]. On a formal level, he also closely adhered to the skaz-narrative technique and utilizes a structure, typical for oral narrative. For example, we find some of the functions Vladimir Propp [1968] lists as necessary attributes of a magic folktale. Storozhenko does not have all of them since his tale is a literary creation after all and somewhat closer to the genre of the legend than the folktale, but there is enough to help create an allusion. The events in "Devil in Love" unfold in an episode where Kyrylo finds himself in need of a horse, because his old one has been killed in battle. This corresponds to a function, which Propp designates as "lack" (designation: $a$ ) and lists as a requirement for a folktale, because it sets a hero on a journey (the so-called "departure" function [designation: $\uparrow$ ]) - hence, Kyrylo travels to find a new horse. In the midst of his journey, while in a state of semi-sleep, he meets the Devil and the witch, and manages to outwit the Devil so that the latter transforms himself into a horse and becomes his servant (this function is called "provision or receipt of a magical agent" [designation: F]). The Devil transports him and Odarka to the hermit who advises the hero and his beloved on how to save their souls (function: "spatial transference between two kingdoms, guidance" [designation: G]). What makes Storozhenko's story different from a folktale is a lack of explicit direct combat between the hero and the adversary (function: "struggle" [designation: H]). However, the Devil does disappear after Kyrylo completes his military service (function: "victory" [designation: I]). Given my presupposition that the Devil in this tale is the "inner" 
adversary of Kyrylo, the one that is located inside his mind, we have instead a literary take on the folkloric function of a combat or struggle. Here, it is an inverted, psychological struggle between the two, rather than an external battle.

In summary, this folkloric framework, in which Storozhenko's tale is set, is one of the chief reasons why Ukrainian scholars assumed that Storozhenko drew on folklore alone and did not go in their investigations beyond strictly folkloric or Ukrainian Romantic tradition. The only other author to whose oeuvre Storozhenko's tale was compared is his predecessor Gogol'. Khropko, for instance, finds many similarities between Storozhenko's "Devil in Love" and Gogol"'s Ukrainian tales from Вечера на хуторе близ Диканьки [Evenings on a Farm near Dikanka, 1831 and 1832], but even then he keeps his comparison within the folkloric context, noting that Storozhenko follows oral tradition more closely than Gogol'. (14) No attempts have been made to search for other literary antecedents behind Storozhenko's tale.

\section{Storozhenko and the Gothic}

It is very possible that Storozhenko knew Cazotte's Gothic novella, either in a Russian translation or the original. (15) Cazotte's romance was immensely popular in Europe, and his name and oeuvre received frequent mention in the literature of the Russian Empire. (16) As Rostislav Schulz notes, an anonymous translation of Cazotte's novella and the four volumes of his collected works were in the library of Alexander Pushkin (1799-1837), who even attempted to write his own version of Cazotte's notorious love-stricken devil, "Влюблённый бес" (ca 1821-1823) [1987: 7, 10; 91-98]. As an officer in the Russian Imperial army and a holder of various responsible bureaucratic posts later in his life [Khropko 1989: 7-8], Storozhenko must have been acquainted to some extent with the literary world of the capital and could have also read Cazotte.

We know for certain that Storozhenko was familiar with other texts of the European Gotho-frenetic tradition, to which Cazotte belongs, whose plots he also adapted and reworked within a Ukrainian cultural setting. I draw this conclusion on the basis of his letter from 13 December 1873 to his publisher and friend Vasilii Belyi, in which Storozhenko mentions his other work, the novel Марко проклятий [Marko the Cursed, 1870-1879] and its sources: 
Существует у нас поговорка: 'товчеться, як Марко по пеклу'. Стало быть, в изустном предании народа должна существовать и легенда похождений Марка, и вот 30 лет отыскивал я и собирал куски раздробленной легенды и кое-что собрал. Каждый народ имеет своего скитальца: франиузы-вечного жида Сантенера, испанџь-Мельмота, у немцев и англичан так их много, что не перечтешь, у русских-Кащей Бессмертный, а у нас-Марко. И, кажется, наш-то Марко заткнет за пояс всех скитальцев [Storozhenko 1989b: 563].

[We have a (Ukrainian or local-SK) saying: "he gads about as Marko did in hell." Therefore, our folklore should have a legend of some sort about Marko's wanderings. I searched for it for 30 years, putting pieces of this scattered legend together, and have gathered some material. Each nation has its own wanderer: the French have the Centenarian, the Spanish have Melmoth, the Germans and the English have so many of them that it is impossible to count them all, the Russians have Kashchei the Deathless, and we have Marko. And it seems that our Marko can outdo them all] [italics are mine-SK].

In this letter, Storozhenko names three major prototypes for the construction of his own, Ukrainian version of the eternal wanderer, Marko: the French Santener, the Spanish Mel'mot and the Russian Kashchei Bessmertnyi. As we can gather from the quote, he seems to either consider all three of them as folkloric personages or uses their names without naming the authors with the understanding that in his milieu everyone would know exactly who they were. In any case, the Russian Kashchei is an evil creature from folklore. But the two other "wanderers" have no prototypes in folklore, save for the universal legend of the Wandering Jew. In fact, they come from two major Gotho-frenetic literary texts: Balzac's novel Le Centenaire [The Centenarian or the Two Beringhelds] (1822) and Maturin's Melmoth the Wanderer (1820). This offers us indirect proof that Storozhenko was indeed familiar with the Gothic literary tradition, be it either through the originals or some anonymous and, most probably, abridged Russian translations of Gothic novels, which might have identified them as simply West European folktales (and the first Russian translations of Cazotte's tale did associate it with folklore (17)).

Whether or not Storozhenko knew who the author of The Devil in Love was, he must have liked Cazotte's original plot about the lovestricken devil and decided to adapt it to Ukrainian realia, endowing it with the mythologized setting of the Ukrainian Romanticized steppe and selecting the main characters from Ukrainian historical, legendary and folkloric traditions: a Cossack instead of an imperial military person; a witch instead of a sylphid; and a hermit instead of a family confessor. 
This would explain both the folkloric allure of Storozhenko's tale and its close textual proximity to Cazotte, along with the identical title.

However, before I am able to affirm with certainty the intertextual ties between Storozhenko and Cazotte and before I can elaborate upon the peculiarities of the Gothic mode that Storozhenko constructs, following the French Gothic novella, I still need to consider the possibility of a coincidence. Is there in fact some European ur-myth or $u r$-tale about the 'devil in love', which incorporates many of the same folk motifs that reappear in Cazotte and Storozhenko and which, in its respective French and Ukrainian variations, could have served as an independent source of inspiration for both authors?

\section{The folkloric origins of the narrative 'devil in love'}

In search for the origins of the 'devil in love' narrative, I turn to Antti Aarne's The Types of the Folktale: A Classification and Bibliography. Written in 1910, enlarged by Stith Thompson in 1961 and updated by Hans-Jörg Uther in 2004, the Aarne-Thompson-Uther classification system groups folktales by motifs, be they a character, an important item or object in a tale, an action, etc. Having identified similar motifs in a number of tales, Aarne (and later, Thompson and Uther) classified related tales and assigned a number to them, which led to the establishment of a catalogue of universal tale types, known now as Aarne-Thompson-Uther types (ATU types).

A detailed look at the index, however, does not reveal a specific type and/or subtype upon which the 'devil in love' could be based. In fact, the ATU types pertaining specifically to the Devil have very little in common with the plot of 'the love-stricken devil'. They focus instead on the image of the Devil as an evildoer or the Devil as a trickster (and an unlucky one at that), whose attempts to capture human souls are more often than not overturned either by God, saints, or a witty protagonist. (18) In fact, many tales from the collections of Ukrainian folklore that I considered above when searching for a legend about the love between the Devil and the witch, identified by Khropko as the base for Storozhenko's tale, follow these tale types closely. This once again points to the fact that Storozhenko's tale may have a folkloric allure, but no real folkloric ground.

On the level of the tale type title, the closest to Storozhenko (and Cazotte) could be the tale types 1476B (Devil as husband) and 311 (Devil as suitor), which invoke the motif of the Devil acting as a 
paramour but their plots develop differently. My previous psychoanalytical reading showed that the Devil in Storozhenko's and Cazotte's tales acts as a symbol of the repressed dark sexual desire of the main protagonist [Pavlunik (Krys) 2006: 27-34]. In Cazotte, the Devil represents the latent homosexual urge of his main character, Alvaro. This is seen through the ambiguous gender identity of the sylphid, with whom the protagonist falls in love and the final scene, where Alvaro's beloved comes to him in the threatening image of Beelzebub (the masculine symbol). In Storozhenko, the Devil who literally mirrors the Cossack Kyrylo Kelep's actions and appearance anthropomorphizes his suppressed sexual desire for a woman whom he had left at home when he went to serve at the Sich. On the other hand, the plot of the tale type about the Devil as husband, which the ATU index offers, is an example of an anecdote about old maids who cannot find husbands and are so desperate that they would even agree to marry the Devil himself. (19) The focus here is shifted toward the female protagonist, rather than resting on the male protagonists and the Devil, as it does in the two written works under analysis. Moreover, this tale type features no masculine protagonist who could serve as the Devil's adversary and the rescuer of the heroine. The plot of tale type 311 (Devil as suitor) is also quite different. It belongs to the tales of magic and narrates the fate of three sisters who are taken by a demon and how the youngest sister tricks the demon and manages to escape and sometimes also rescue her siblings. (20) As we see, the focus here again is on the female protagonists and the ordeal they must overcome. Thus, neither of the two could serve as an $u r$-tale for the stories under analysis.

Since the search for 'the devil in love' narrative returned no results, I expanded the query criteria to a wider category. First, I considered the "love" category but it did not contain any type, related to the tales under analysis [Uther, 2004, 3: 215]; therefore, I broadened the search parameters to 'the Devil' per se, basing myself on the first part of the narrative's theme. The broader category that includes 'the Devil' theme- "supernatural adversaries"-offers us some parallels with the following tales of magic where the Devil or his various hypostases (e.g., the Ogre, Giant, Dragon, Cobold, Magician, Cannibal, etc.) are defeated. (21) The Devil is indeed overcome in both Storozhenko and Cazotte, owing to the hero's adherence to the advice of a holy man. However, the Devil paradigm in Cazotte and Storozhenko does not symbolize simply an encounter with evil and a victory over it or the fulfillment of a quest, as it would in a folktale; it possesses a complex psychological meaning. 
In this it differs from the abovementioned ATU tale types' cluster. The psychological dimension surfaces in each narrative thanks to a special emphasis on the dream state of the protagonists, in which they first come in contact with the supernatural realm. Thus, unlike a typical fairy-tale where the supernatural is an integral part of the fictional universe, "Devil in Love" by Storozhenko and The Devil in Love by Cazotte both betray an element of doubt as to whether the hero indeed experienced the encounter or he simply dreamt it. The narrator of Cazotte's novella mentions the possibility of a dream or a nightmare, when speaking about Alvaro's analysis of his relationship with the Devil. According to Tzvetan Todorov, "[...] Alvaro hesitates, wonders (and the reader with him) whether what is happening to him is real, if what surrounds him is indeed reality (in which case sylphides exist), or whether it is no more than an illusion, which here assumes the form of a dream" [1975: 24]. In fact, Alvaro himself suggests such possibilities. He states,

She [Biondetta, the Devil-SK] took hold of my senses and offered me the most pleasant of dreams, the sort best fit to rest my soul from the frightful, outlandish ideas that had so wearied it. It was, moreover, a very long sleep, and my mother, reflecting one day on my adventures, would later claim that it was not a natural slumber [Cazotte 1993: 25].

A similar situation obtains in Storozhenko's work. The main character of its inner story, Kyrylo Kelep “сів [...] собі під кущем підождати, поки зійде місяць, та й задрімав. Аж чує крізь сон-наче хто його тягне [...]" [sat (...) under the bush to wait for the moon to rise, and fell into slumber. When suddenly, through his dream, he feels, as if someone is dragging him (...)" [1989: 72]. The emphasis on the dream state of each protagonist strengthens the hypothesis that the Devil presents a symbolic visualization of something inside the protagonist's mind, which breaks through his defense mechanisms during his sleep. Hence, in Cazotte and Storozhenko the focus moves from the idea of a quest by the protagonist, which is realized in the defeat of a supernatural adversary and a marriage of a princess, to the psychology of the protagonist and his behavior at the time when he is split between his societal duties and sexual desires that need to be subdued. He does fight the external adversary, but this adversary is the one that is inside his own mind.

The second broader category we can consider in relationship to the development of the plot of both works is the "supernatural or enchanted wife" (ATU 400-424 [Uther 2004, 1: 231-247]), where the Devil also appears. (22) The elements of the tale types from this category are 
present in Cazotte's and Storozhenko's narratives, but to a much lesser degree, since the focus of both works is on the protagonist and his "inner" adversary (i.e., the Devil) - hence, the name both authors gave to their tale is 'the devil in love', and not 'the devil and X' (e.g., the princess). This tale type cluster finds its equivalent in a witch ("enchanted princess") whom Kyrylo Kelep rescues from the grips of the Devil. Storozhenko seems to adhere to this category more closely, in a sense that he presents the witch Odarka as an innocent girl possessed by evil with whom his protagonist falls in love and whom he tried to rescue from the Devil. In this he differs from Cazotte, who modifies this tale type heavily. The bewitched Biondetta who captures Alvaro's heart turns out to be evil itself. Thus, the "enchanted princess" type finds a negative interpretation in the French text. Here it is a villainous and treacherous "succubus" or even "incubus" if we remember that this being takes on both feminine and masculine forms (Biondetta and Biondetto), and, moreover, that behind its human façade lurks the Devil himself. In fact, it is the male who becomes the victim of the evil being's advances in Cazotte's tale, which offers an interesting literary take on, and even a reverse of, traditional folktale gender roles.

While both texts do show elements of a few ATU folktale types, there is not a single specific type, which could serve as an archetype for the 'devil in love' narrative. Moreover, we see that both authors similarly complicate and modify the elements of the tale types they use, adding psychological dimensions and artistic twists to them. While one would expect that from an artistic work, we would not normally find similar developments and points of emphasis, let alone identical titles, in two stories by different authors unless there is a significant literary borrowing and intertextual connection that the later text projects onto the one that was written before. While the presentation of a demonized female character differs in Storozhenko and Cazotte (23), the main protagonists seem to be very similar to each other. In fact, in the persona of Kyrylo Kelep who is fighting with his inner Devil we have almost a mirror image of don Alvaro who is going through the same ordeal.

\section{Conclusions}

To conclude, besides the absence of a clearly identifiable folktale type on which Storozhenko's tale could be based, i.e., independently from Cazotte, the Ukrainian text contains a number of features that, despite its overall folkloric allure, make it a specific literary creation and 
draw it closer to Cazotte's text. One such feature is a certain skepticism and doubt toward the existence of the supernatural, which comes about due to the perspective of a contemporary, rational narrator, who sees an encounter with the supernatural as a form of psychological distortion and madness, as errors of perception or even as a lie. To such blurring of subjective and objective realities we can add another feature, namely, the complicated treatment of good vs. evil. Like Cazotte, Storozhenko depicts evil, which at times assumes distinctly positive qualities. In Cazotte, Biondetta(-o) is simultaneously an embodiment of the darkest evil and a faithful servant to don Alvaro; in Storozhenko's narrative, the Devil is at once an evil seducer and usurper of the witch's freedom, but also a loyal servant to Kyrylo Kelep; his death even induces tears from the audience and the protagonist himself. This shows that Cazotte and Storozhenko both evoked the 'demon lover' literary trope (that was embraced, modified, and metaphorized by the writers of the Gothic, Schauerromantik and far beyond), where evil was portrayed simultaneously as appalling and causing feelings of compassion. These factors together with the already mentioned psychologization of his narrative testify to the fact that Storozhenko offered a literary stylization and a Romantic reworking of some general folktale types and motifs but did not follow one specific fairy-tale or legend. Thus, the close textual and symbolic proximity to Cazotte in Storozhenko's tale, which I proved on the level of narrative development and latent content in my previous article, is now strengthened by the absence of a universal prototype of 'the love-stricken devil' plot, which reaffirms that Storozhenko was following a particular example of the frenetic Gothic tradition.

Like Cazotte, whose vision of the Gothic stemmed from his fascination with fairy stories and Oriental tales (along with the occult) (24), Storozhenko also united the frenetic Gothic framework and the oral tradition into a tight bundle. However, unlike his French predecessor, who, for the most part, utilized exotic folkloric element and location (e.g., Spain) in his novella, Storozhenko turned to local lore and constructed a specifically Ukrainian literary world of horrors. In this world, the Ukrainian Cossacks took the place of aristocratic protagonists, an itinerant bard instead of a Gothic manuscript assumed the role of conductor to the mysterious past, the Ukrainian steppe served for the disconcerting unfamiliar realm, and the pantheon of Ukrainian mythological daemons substituted the world of sylphides and other spirits. This "imagined" folklorism that we see in "Devil in Love" not only became a distinct feature of Storozhenko's Gothic prose on the 
whole, appearing most prominently in his longer novel Marko the Cursed, but also became a highlight of the Ukrainian Gothic canon in general.

\section{NOTES}

1 I would like to express my sincere gratitude to my supervisor, Prof. Oleh S. Ilnytzkyj (University of Alberta), for his useful comments, many of which I incorporated into my text, and for editing a draft version of this work. I am also indebted to the two anonymous readers of Folklorica and, especially, to the Editor, Prof. Natalie Kononenko, for their constructive insights, comments, and suggestions for revisions, which were very helpful in shaping the present version of this article.

2 For an example of Ukrainian witchcraft beliefs and the "demonization" of spouses/girl-friends as "witches" (to justify, among other things, unruly and antisocial behavior towards them) see Kononenko 1998: 67-90. Kononenko's article analyzes folktales about witches (presented as fabulates) that were collected by Volodymyr Hnatiuk at the beginning of the twentieth century.

3 I should note that while both the horse and camel are good for riding, and Storozhenko indeed employs the motif of Kyrylo riding the Devil, this option is not actualized in Cazotte's novella. I thank the anonymous reviewer for this observation.

4 “'[...] оповідання 'Закоханий чорт', основане на повір'ї про кохання між чортом і відьмою та переказах про кмітливість запорожців."

5 For an analysis of Ukrainian legends about Cossacks and magic, see Shiyan 2006: 109-124.

6 See "Чорть въ видь клубка" [The Devil As a Ball of Wool], "Чортъ въ видъ борзой собаки" [The Devil As a Hound], "Чортъ въ видъ пана" [The Devil As a Nobleman] [Dragomanov 1876: 44-46, 47]; "Чортъ конемъ" [The Devil As a Horse], “Чорть панычемъ на пасици" [The Devil As a Young Nobleman at the Apiary] [Grinchenko 1901: 90-91]; “Безпятий панич” [A Young Nobleman Without Heels], "Чорт когутом" [The Devil As a Rooster], "Чорт у видї чорного песика зникає з комори" [The Devil Disappears from the Storage in a Shape of a Small Black Dog], "Чорт у видї вояка" [The Devil As a Soldier], etc. [Hnatiuk 1912: 6, 13-15]; "Чорт-баранчик" [The Devil As a Lamb], “Як чоловік із чортом гуслі міняв" [How a Man Traded His 
Psaltery with the Devil], "Чорти-мірошники" [The Devils-Mill Workers] [Ioanidi 1985: 55-56].

7 “Чортъ заводитъ человъка съ дороги" [The Devil Leads a Man Astray], "Чортъ топитъ извощика" [The Devil Drowns a Cart Driver] [Dragomanov 1876: 54]; "Кого бере ся чорт" [Whom Does the Devil Take?], "Через чорта божевільний” [How a Man Lost His Mind Because of the Devil], "Чорт топить чоловіка" [The Devil Drowns a Man] [Hnatiuk 1912: 15-16, 27]; “Як чоловік в чортовім палаці був” [How the Man Visited the Devil's Palace], "Біс фурманом" [The Devil as a Cart Driver] [Levchenko 1928: 22-23]; "Зустріч 3 чортом" [Meeting with the Devil] [Zinchuk 2003: 344-345].

8 “Какъ вызывать чертей” [How to Conjure the Devils], "Какъ добыть чорта-слугу" [How to Turn the Devil into One's Servant] [Dragomanov 1876: 56-57]; “Як дістати біса на послуги” [How to Get the Devil to Serve You] [Levchenko 1928: 18].

9 “Як хлопець дїтька змудрував" [How a Lad Outwitted the Devil], "Чоловік ловить чортів у торбину" [A Man Catches the Devils in a Bag], "Салдат і чорти" [A Soldier and the Devils] [Hnatiuk 1912: 58-64]; “Старець визволяє запродану чортам душу” [A Hermit Saves a Soul, Pawned to the Devils], “Як дядько чорта дурив і діжку грошей від нього здобув" [How a Man Fooled the Devil and Got a Pot of Money from Him] [Levchenko 1928: 31, 35-36].

10 See "Чорт мордує дївку" [The Devil Kills a Girl], "Чорт роздирає жінку" [The Devil Tears a Woman Apart], "Біс у молодици" [A Woman Possessed by the Devil] [Hnatiuk 1912: 48-53]; "Біс ходить до жінки, хортом перекидаючися" [The Devil Comes to a Woman in a Guise of a Greyhound], "Як біс-домовик задушив дівку (Сказка, що чорт дідову дівку задусив)" [How the House Spirit Suffocated a Girl (A Tale About the Devil Suffocating the Old Man's Daughter)] [Levchenko 1928: 20, 24-25].

11 One important exception is a tale in Levchenko's collection where the old woman managed to save the human soul, which was pawned to the devils. See "Як розумна баба запродану чортам душу вратувала" [How a Clever Old Woman Saved a Soul, Pawned to the Devils] [1928: 33-34].

12 I thank the anonymous reviewer for this information.

13 See "T91.2. Love of mortal and devil," "T91.2.1. Devil would be maid's paramour," "T91.3. Love of mortal and supernatural person" [Thompson 2000: Volume 5: L-Z]. 
14 “Легендарно-фантастичне оповідання 'Закоханий чорт' позначене певним наслідуванням романтичної манери молодого М. Гоголя. Типологічна схожість цього твору 3 оповіданнями із 'Вечорів на хуторі біля Диканьки' виявляється в тому, що сюжет побудований на демонологічному матеріалі, реальне химерно переплітається із фантастичним, щедро використані образи народної сміхової культури [...] Звичайно, письменники різнилися художнім обдарованням. До того ж О. Стороженко, на відміну від М. Гоголя, міцно тримається легенди чи повір'я і не надає ширшого польоту своїй уяві" [Khropko 1989: 14]. [In his legendary-fantastic tale "Devil in Love," Storozhenko follows to a certain extent the Romantic style of young Gogol'. The typological similarity of his story with the tales from Gogol'"s Evenings on a Farm near Dikanka can be seen in the fact that their plots are constructed on folk mythology and demonology, the real world there is tightly interwoven with the fantastic, both authors fully use images from folk humor (...) (But) of course, both authors were different in terms of their artistic style. Moreover, as opposed to Gogol', Storozhenko closely follows a legend or a folk belief and does not allow his imagination to fully take over.]

15 Khropko notes that Storozhenko studied French in the Kharkiv gymnasium [Khropko 1989: 7].

16 There was also a French ballet based on Cazotte's romance; it was staged at the Imperial Theatre (Большой Каменный) in St. Petersburg in 1848 under the title "Сатанилла" ["Satanilla," n.d.]. I thank the anonymous reviewer for pointing this out to me.

17 Cazotte's novella was initially translated into Russian as "A Love-Stricken Spirit or Adventures of Don Alvaro" and appeared in print in Moscow in 1794 as part of collected folkloric texts, titled "The Same Tune in a New Setting or Complete Collection of Old Folk Tales." [“"Влюблённый дух, или Приключение Дона Альвара'. Старая погудка на новый лад, или Полное собрание древних простонародных сказок (Москва, 1795 [sic])" (Schulz 1987: 10).] Schulz mistakenly offers 1795 as a date of the publication. The collection The Same Tune in a New Setting [Старая погудка на новый лад] where Cazotte's novella was reprinted indeed appeared in a few volumes between 1794-1795, but Cazotte's novella was published in a volume that came out in 1794. See V. M. Zhirmunskii and N. A. Sigal for correct date [1967].

18 The list in the ATU index pertaining to the "Devil" is rather long. Here is a representative selection of several tale types, where he 
appears: "Devil abducts princess 301, abducts princesses 301, abducts rich man 832 , abducts several brothers $327 \mathrm{G}$, advises woman to procure abortion by using magic 755 , already dead (cannot collect money) $822 *$, always blamed 846 , and animal 1131, and farmer 1059*, and farmhand 1132, 1153, and girl 1180, and God 1030, 1184, and God dispute 773**, and God frighten one another 1145, and God have contest of creation 773, and helper 1048, and lawyer 1186, and man 1000-1190*, and old woman 1353, and servant 475, and smith 330 , and thunder-god 1148B, and woman 1169, 1172, 1176, 1180, 1183, 1187, 1188, 1192, 1199, 1199A, annoyed by crossed straps on soldier's knapsack 1168, as creditor cheated $822^{*}$, as God's greatest enemy 1425 , as helper 832, 1187,1191 , as host at dinner $821 \mathrm{~B}^{*}$, as husband $1476 \mathrm{~B}$, as master builder $810 \mathrm{~A}^{*}, 1191$, as mower $752 \mathrm{C}, 820 \mathrm{~B}$, as mythical creditor $822^{*}$, as suitor 311 , as unfaithful companion forces change of roles 531, asks shoemaker to make shoes for him (shoe his horse) $815^{*}$, at confession $818^{*}$, at grindstone $1178^{* *}$, called by carelessly spoken word (curse) 813A, cancels contract 756B, cannot accomplish impossible task 11711180 , cannot endure cross $1166^{*}$, cannot endure quarrelsome wife 1164 , cannot overcome magic tool $811 \mathrm{~A}^{*}$, cannot solve riddles 1178 , carries off lawyer 1186, carries off man 813B, carries off old maid 1476B, carries weaver in a sack 1177, demands compensation 1184, claims first being to cross bridge 1191, claims soul 1188, defeated in fight with man 305 , demands to spend first night with bride 1165 , devours corpses 407 , escapes 1188, 1199A, expelled 1147*, 1164, 1168C, expels Solomon (other person) from hell $804 \mathrm{~B}$, fears crucifix 1168, fears magic circle 1168 , fears shoemaker 1168, fears thunder and lightning 1165, fears Virgin Mary $1168 \mathrm{C}$, forged to chain 803 , freed by hunter 1164 , frightened by wolves 1150, frightens false ghost 1676, fulfills labor contract 810A, gives magic stone to man 593, gives up trying to guard unmanageable wife 1352, has to do penance $810 \mathrm{~A}$, helpless against strong man 650A, helps slandered man 571B, helps with haying (mowing) 820B, ignorant of object 1650 , in bottle 862 , in disguise $815^{*}$, 839A*, 921B," etc. [Uther 2004, 3: 168-169].

These tale types belong to a variety of genres, such as tales of magic, religious tales, and anecdotes. I offer them here to show that not one type, dealing specifically with the Devil, has anything in common with the plot of 'the love-stricken devil'.

19 “1476B Old Maid Married to a Devil’ (previously Girl Married to a Devil). [...] An old maid who is tired of living alone cries out in despair, 'I would even marry the devil, if he would have me!' The devil 
comes and carries her off (marries her). [G303.12.5]" [Uther 2004, 2: 236].

20 "311 Rescue by the Sister. Two sisters, one after the other, fall into the power of a demonic suitor (cannibal, dragon, magician, devil) and are taken into his (subterranean) castle [R11.1, T721.5]. There the sisters open a forbidden room full of dead bodies, in the course of which the key (a magic egg, apple) becomes bloody, or they refuse to eat human flesh [C611, C227, C913]. The demon kills them for their disobedience [C920].

Using a trick, the third (youngest) sister escapes from the same fate. She finds her sisters and resuscitates them by putting their bones together [R157.1]. She hides them beneath some gold in baskets (bags) and persuades the demon to carry the baskets home without looking into them [G561]. Cf. Type 1132.

The youngest sister pretends to marry the demon and leaves a skull (straw dummy) dressed as a bride to deceive him. Unwittingly the demon carries this sister home in the third basket. Or she smears herself with honey and feathers and escapes as a 'strange bird' [K525, K521.1]. Cf. Types 1383, 1681. The demon is burned in his own house or is killed in another way [Q211]. Cf. Type 312" [Uther 2004, 1: 191].

21 ATU 300-399, see especially the category "Dragon-slayer" (ATU 300, 303, 305, 314, 315, 317, 321, 328A*) [Uther 2004, 1: 174].

22 There is also a broader category of "supernatural or enchanted husband" (ATU 425-449 [Uther 2004, 1: 247-265]) that includes a subcategory "animal husband." Given the fact that the Devil in both stories, and especially Storozhenko's, takes a form of an animal, I have also considered the tale types from this subcategory but they turned out to be quite different. Again, the focus was shifted toward a female personage who wronged her animal husband by exposing his secret/burning his animal skin and had to set out on a difficult quest to redeem her actions and reunite with her husband. Consider, for example, ATU 425A "The Animal as Bridegroom" [Uther 2004, 1: 248-249].

23 Such a difference between Cazotte and Storozhenko could be explained by the fact that in depicting Biondetta/Biondetto as succubus/incubus Cazotte draws heavily on Christian demonology and written sources (such as the writings of the famous alchemist and occultist, Paracelsus [1493-1541], see V. M. Zhirmunskii and N. A. Sigal [1967]).

24 Cazotte's fascination with fairy-tales and folklore resulted from the eighteenth-century French vogue for fairy stories and especially 
Oriental narratives. Cazotte himself published a story very early in his career as a writer, which imitated the contemporary vogue for Oriental tales, La Patte du chat, Conte zinzimois (ca 1740-1741). Also, in 1788 he published in Geneva Suite des mille et une nuits-"a collection of Oriental tales adapted from an Arab manuscript translated by Dom Chavis and recast by Cazotte" [Sieburth and Gordon 1993: 161, 165; see also V. M. Zhirmunskii and N. A. Sigal (1967)].

\section{BIBLIOGRAPHY}

Baziuk, Uliana. 2003. Базюк, Уляна. “Легенда про великого грішника та ii фольклорно-літературні інтерпретації (на матеріалі української романтичної прози XIX ст.)" [The Legend about a Great Sinner and Its Folk and Literary Interpretations (Based on the 19th-Century Romantic Prose)], Вісник Львівського Університету: Серія філологічна 31: 165-178. Also available online: http://www.Inu.edu.ua/faculty/Philol/www/visnyk/31/zcf.doc (consulted 17 February 2010).

Cazotte, Jacques. 1993. The Devil in Love. New York: Marsilio.

Dragomanov, Mikhail, comp. 1876. Драгоманов, Михаил, сост. Малорусския народныя предания и рассказы [Little Russian Legends and Tales]. Издание Юго-Западнаго Отдела Императорскаго Русскаго Географическаго Общества. Киевъ: Типография М. П. Фрица.

Grinchenko, Boris, comp. 1901. Гринченко, Борис, сост. Изъ усть народа: Малорусскіе разсказы, сказки и пр. Черниговъ: Земская Типографія.

Hnatiuk, Volodymyr, comp. 1912. Гнатюк, Володимир, упор. “Знадоби до української демонологіï” [Contributions to Ukrainian Folk Beliefs about Spirits] Етнографічий збірник Наукового Товариства Шевченка 33-34. Львів.

Ioanidi, Anatolii, comp. 1985. Іоаніді, Анатолій, упор. Легенди та перекази [Legends and Memorata], "Українська народна творчість." Київ: Наукова думка.

Ishchuk, Arsen. 1957. Іщук, Арсен. "Олекса Стороженко," in Твори у двох томах [Works in 2 Volumes]. Київ: Державне видавництво художньої літератури. 5-18.

Khropko, Petro. 1989. Хропко, Петро. “Олекса Стороженко і його літературна спадщина" [Oleksa Storozhenko and His Literary 
Legacy], in Марко проклятий. Оповідання [Marko the Cursed.

Short Stories]. Олекса Стороженко. Київ: “Дніпро.” 5-20.

Kononenko, Natalie. 2007. Slavic Folklore: A Handbook. Greenwood

Folklore Handbooks. Westport, Connecticut and London:

Greenwood Press.

Kononenko, Natalie. 1998. "Strike Now and Ask Questions Later:

Witchcraft Stories in Ukraine," Ethnologies 20.1: 67-90.

Lepkyi, Bohdan. 1954. Лепкий, Богдан. “Олекса Стороженко," in

Марко Проклятий. Олекса Стороженко. Нью Йорк: В-во

"Говерла."

Levchenko, Mykola, comp. 1928. Левченко, Микола, упор. Казки та

оповідання з Поділля в записах 1850-1860-их рр.: Випуск I-II

[Magic and Folk Tales from Podillia Region as Recorded in 1850s-

1860s: Issues I-II]. Київ: Українська Академія Наук.

Moyle [Kononenko], Natalie. "Folktale Patterns in Gogol"s Vij,"

Russian Literature 7 (1979): 665-688.

Pavlunik [Krys], Svitlana. 2006. Павлунік [Крис], Світлана.

““Закоханий чорт' Стороженка та 'Закоханий диявол' Жака

Казота: Спроба компаративного аналізу" [An Attempt at a

Comparative Analysis of Oleksa Storozhenko's "Devil in Love" and

Jacques Cazotte's The Devil in Love], Слово i час 9: 27-34.

Pohriebennyk, V. 2008. Погрєбенник, В. “Традиційна українська культура у творчості Олекси Стороженка" [Ukrainian Folk Culture in Oleksa Storozhenko's Oеиvre], Украӥнська література в загальноосвітній школі 4: 2-7. Also available on-line: http://www.ukrlit.vn.ua/article1/1474.html (consulted 10 July 2011). Propp, Vladimir. 1968. Morphology of the Folktale. 2nd ed. revised and edited with a Preface by Louis A. Wagner. New Introduction by Alan Dundes. Austin, TX: University of Texas Press.

Sartarelli, Stephen. 1993. "Preface," in The Devil in Love. Jacques Cazotte. New York: Marsilio.

"Satanilla," n.d. "Сатанилла, или любовь и ад." Русский балет.

Онлайн энциклопедия [Russian Ballet. On-line Encyclopedia].

Cited by http://www.pro-ballet.ru/html/s/satanilla.html> (consulted 8 July 2011).

Schulz, Rostislav. 1987. Шульц, Ростислав. Пушкин и Казот [Pushkin and Cazotte]. Washington, DC: Ross Press.

Shiyan, Roman. 2006. Cossack Motifs in Ukrainian Folk Legends. PhD Dissertation. Edmonton: University of Alberta. 
Sieburth, R. and J. Gordon. 1993. "Chronology," in The Devil in Love. Jacques Cazotte. New York: Marsilio.

Storozhenko, Oleksa. 1989a. Стороженко, Олекса. "Закоханий чорт” [Devil in Love], in Марко проклятий. Оповідання [Marko the Cursed. Short Stories]. Київ: “Дніпро.” 66-90.

Storozhenko, Oleksa. 1989b. Стороженко, Олекса. Листи [Letters], in Марко проклятий. Оповідання [Marko the Cursed. Short Stories]. Київ: “Дніпро.” 561-586.

Thompson, Stith. 2000. Motif-Index of Folk-Literature. Electronic edition. Charlottesville, Virginia, USA: InteLex Corporation. Cited by:

http://www.library.nlx.com.login.ezproxy.library.ualberta.ca/xtf/vie w?docId=motif/motif.00.xml;chunk.id=div.motif.pmpreface.1;toc.d epth $=1 ;$ toc.id=div.motif.pmpreface.1;brand=default\&fragment_id= (consulted 28 September 2010).

Todorov, Tzvetan. 1975. The Fantastic: A Structural Approach to a Literary Genre. Ithaca and New York: Cornell University Press.

Uther, Hans-Jörg. 2004. The Types of International Folktales: A Classification and Bibliography. Based on the System of Antti Aarne and Stith Thompson. Vols. 1-3. FF Communications No. 284-286. Helsinki: Academia Scientiarum Fennica.

Zhirmunskii, V. M. and N. A. Sigal. 1967. В. М. Жирмунский и Н. А. Сигал. "У истоков европейского романтизма" [At the Sources of the European Romanticism], in Уолпол. Казот. Бекфорд. Фантастические повести [Walpole. Cazotte. Beckford. The Fantastic Novellas]. “Литературные памятники." Ленинград: "Наука." Available on-line:

$<$ http://lib.ru/INOOLD/UOPOL/wallpoll0_2.txt> (consulted 30 January 2010).

Zerov, Mykola. 2003. Зеров, Микола. "Брати-близнята (Історія i побут у Стороженковій повісті)" [The Twin Brothers (The History and Everyday Life in Storozhenko's Long Story)], in Українське письменство [Ukrainian Writers]. М. Сулима, упоряд. Київ: “Основи.”

Zinchuk, Mykola, comp. 2003. Зінчук, Микола, упор. Казки Гуиульщини: Книга 1 [Folktales from Hutsul Region: Book 1], Українські народні казки. Львів: Видавництво “Світ." 